\title{
Secret society, secret sources?
}

\section{BOOK TITLE:}

The secret society: Cecil John Rhodes's plan for a new world order

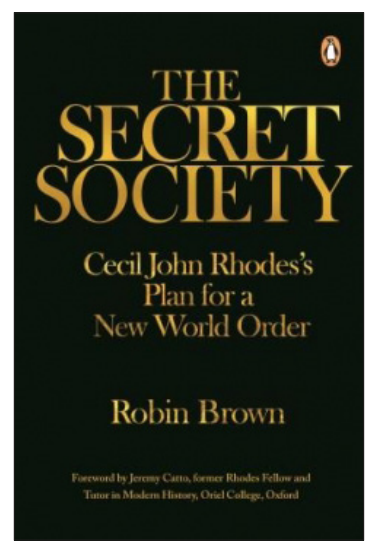

AUTHOR:

Robin Brown

ISBN:

9781770229204 (hardcover)

PUBLISHER:

Penguin, Cape Town; ZAR350

PUBLISHED:

2015

\section{REVIEWER:}

lain Edwards

EMAIL:

edwards.researchsa@gmail. com

\section{AFFILIATION:}

Gordon Institute of Business Science, University of Pretoria, Pretoria, South Africa

\section{POSTAL ADDRESS:}

GIBS, PO Box 787602 ,

Sandton 2146, South Africa

\section{HOW TO CITE:}

Edwards I. Secret society, secret sources? S Afr J Sci. 2016;112(3/4), Art. \#a0150, 2 pages. http://dx.doi. org/10.17159/sajs.2016/a0150

(C) 2016. The Author(s). Published under a Creative Commons Attribution Licence.
Robin Brown's new book concerns Cecil John Rhode's, southern Africa's greatest jingo and racial supremacist, and a figure whose afterlife continues to bedevil South African's attempts to come to terms with their past. Published but months after the \#RhodesMustFall movement began, Brown's South African book launch came with rousing prepublication and publication media fanfare with excerpts of the book appearing across the range of South African media.

Brown's book is not simply another in a long stream of biographies of Rhodes, which although differing in political perspective and historical judgement, all follow a chronological narrative and are remarkably similar in content. Claiming to draw upon hitherto hidden or recently discovered archival sources, Brown's work is episodic, not chronological. The book is as much about Rhodes, who died in 1902, as it is about his afterlife. Included are Rhode's ideas for a secret society to ensure that English-speaking societies worldwide fashioned and controlled a global New World Order.

Brown emphasises three issues: one is already known, one long insinuated, and the final one is Brown's pièce de résistance which form the thread through Secret Society: Rhode's wills and attached testimonies, Rhode's homosexuality; and, posthumously, a secret society of powerful and mostly homosexual men wielding unheralded behind-the-scenes power and influence in British and global politics. For Brown, Rhodes is seeking to shape the future - making history - from beyond the grave.

In a dramatic statement on Rhode's intentions, Brown quotes Rhodes as writing in his Confession, in 1877:

I leave all my worldly goods in trust (to the Secretary for the Colonies, Lord Carnarvon, and Sydney Godolphin Shippard now of the Inner Temple) to and for the establishment, promotion and development of a Secret Society, the true aim and object thereof shall be the extension of British rule through the world, the perfecting of a system of immigration from the United Kingdom, and of colonisation by British subjects of all lands where the means of livelihood are attainable by energy, labour and enterprise, and especially the occupation by British settlers of the entire Continent of Africa, the Holy Land, the Valley of the Euphrates, the islands of Cyprus and Candia, the whole of South America, the Islands of the Pacific not heretofore possessed by Great Britain, the whole of the Malay Archipelago, the seaboard of China and Japan, the ultimate recovery of the United States of America as an integral part of the British Empire, the inauguration of a system of Colonial representation in the Imperial Parliament which may tend to wield together the disjointed members of the Empire, and, finally, the foundation of so great a Power as to hereafter render wars impossible and promote the best interests of humanity. (p. 42)

Brown refers to this as 'deranged' (p. 42). In South African press releases at the time of publication, this excerpt featured prominently. Brown provides no citations for this quote and concedes that 'it is unlikely to be entirely [Rhode's] own work' (p. 42). Whatever the questionable provenance is, this excerpt is not from Rhodes Confession of 1877, a full copy of the 'fair copy' version of which is produced in an appendix in John Flint's 1975 biography of Rhodes. ${ }^{1}$

Key to this secret society is the Round Table Movement, and Milner, second chairperson of the Rhodes Trust. It was this trust, and Bailey's 'millions', which funded the formation of the Royal Institute of International Affairs at Chatham House in 1920. It was from here that, according to Brown, the Round Table exerted much influence over the ending of the Great War (p. 303-309), the formation of the League of Nations (p. 316), and the Commonwealth (p. 318) and the editorial policy of The Times. In addition, the Round Table was of key influence in British policy towards Palestine, India and Ireland, as well as in issues relating to the British appeasement policy, the Windsors and abdication, Hitler's foreign policy, and attempts to retain the empire after 1945.

When dealing with a secret society and the Round Table, Brown assumes the existence and importance of this group, then puts evidence in place to confirm such a priori assumptions. Brown continually uses words such as 'perhaps' and 'almost certainly' (p. 185), 'more than likely' (p. 204), 'highly likely', 'unlikely', 'may even', and 'only logical scenario' (p. 210-211). Scholarly analysis is not constructed by repeated inference and supposition.

Rhodes was fascinated by a secret society run along semi-religious lines. He was initiated into Freemasonry whilst at Oxford, yet, in his Confession of 1877, Rhodes clearly expressed his disdain for Freemasonry, as lacking clear purpose and vision beyond itself. However, to take the existence of a secret society, as initiated by Rhodes, and draw a posthumous continuum to Chatham House, the Round Table Movement and with these a hidden hand wielding power of global reach, is another matter.

There are high normative requirements for scholarly studies, most particularly for authors making claims as Brown does. Secret Society lacks a clear analytical structure and is hugely overwritten and repetitive. Readers are continually informed, even on page 329 of a 360-odd page text, that Reginald Baliol Brett - Lord Esher - was a royal whisperer and pederast. Brown displays an astonishingly patronising view of black Africans (p. 53, p.60). Chapters have characteristics of hurried drafts and Brown is often factually incorrect. Bill Clinton's presidential nomination speech was in 1992, not 1981. All 28 chapters have footnotes, but the vast majority are chatty asides, not citations. Throughout the book, Brown quotes, often extensively, from sources without providing citations. Chapter 18 is replete with primary source quotes, but has only two footnotes (p.367), neither of which is a citation. 
Brown has failed to consult key texts, including recent studies, and is unaware of relevant criss-crossing scholarly traditions. Many of Brown's secondary source citations are carelessly unsystematic. The book has no bibliography, let alone a properly ordered one. Did Penguin not notice these highly serious scholarly lapses?

This is compounded by Brown's attitude to primary source material. Granted, secret societies are by definition not open societies. Evidential and empirical care is essential. Unsubstantiated claims are ethically and politically irresponsible, and can be dangerous, particularly so as conspiracy theorists have long taken it for granted that Rhodes, Milner and others in the Round Table were Freemasons bent on world domination. ${ }^{2-5}$

Brown cites no material from at least three important substantial primary collections. Staggeringly, the first two concern Rhodes directly. The first is Rhodes's voluminous personal papers, long housed in Rhodes House and now part of the Weston Library of the Bodleian Library at Oxford. ${ }^{6}$ The second is Rev. John Verschoyle's Cecil Rhodes: His political life and speeches, 1881-1900, a collection held in high scholarly regard.? Brown mentions Verschoyle, of an ancient aristocratic family, but only as a 'dubious vicar', as one of Rhode's favoured male companions, and as a leading member of the aesthete movement mixing in High Society establishment homosexual circles linked to government and the Secret Society. Yet, Brown provides no footnotes which refer to primary evidence or other sources backing up these claims. The third is the British government's Colonial Office archive, which includes material highly critical of Rhodes's activities.

There may be at least one key source (p. 196-198, p.304). After Lord Esher's death, his son Maurice collected and compiled his father's writings into two 'massive volumes' (p. 196). Brown writes:

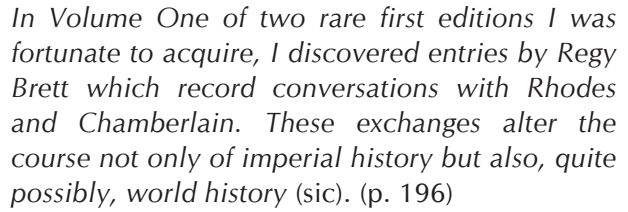

Brown simply and inadequately cites this key source as 'Brett's Journals' (Chapter 16, footnote 4). However, as Esher died in 1930, these journals can hardly account for all the unreferenced primary source material Brown uses so extensively to posit for his Secret Society influence in the first half of the 20th century.

In his acceptance speech at the Democratic National Convention in 1992, Clinton made positive mention of Carrol Quigley, one of his professors whilst an undergraduate at Georgetown University. Clinton noted that Quigley 'said to us that America was the greatest country in the history of the world because our people have always believed in two things: that tomorrow can be better than today and that every one of us has a personal, moral responsibility to make it so'. ${ }^{8}$ In his autobiography, Clinton expands on why Quigley made such an impression on him, to the extent that '[f]rom the 1992 campaign through my two terms in office, I quoted Professor Quigley's line often, hoping it would spur my fellow Americans, and me, to practise what he preached'. Clinton's reasons for respecting Quigley are perfectly appropriate. Quigley was an eminent and inspiring scholar of civilisations. ${ }^{9}$ However, at the time and shortly after the Democratic Convention, Clinton's attitude to Quigley aroused curious comments. For Quigley, who died in 1977, was not only a renowned theorist of the evolution of civilisations, but also intent upon exposing an Anglo-American elite cabal influencing global affairs. Amongst Quigley's other public supporters was the ultra-conservative John Birch Society. To many, Quigley was not only an historian, but also a conspiracy theorist. ${ }^{10}$

Professor Quigley's main area of research was on the Rhodes-Milner Round Table group and its influence on British, Anglo-American and global affairs in the first half of the 20th century. Quigley's research was first published, seemingly obscurely, in 1949, but then later published in 1981. ${ }^{11}$ Brown acknowledges Quigley's work, citing it twice (p. 237-238, p.260). Quotes from unacknowledged primary sources appearing in Quigley's work also appear, unacknowledged, in Brown's work. (e.g. p. 300, p. 317). Quigley did not write on homosexuality. He did have a secret source within The Round Table Movement, but never uses the term the New World Order

Robin Brown needs to provide a professionally listed bibliography of consulted sources; clarify, in accordance with scholarly protocols, the provenance of his references and quotes; and explain why core primary and secondary sources - surely material essential to his dramatic publicity-claiming assertions - show no signs of having been consulted. Failing this, Secret Society has no legitimacy.

\section{References}

1. Flint J. Cecil Rhodes. Boston, MA: Little, Brown and Company; 1975. p. 248-252

2. The Rhodes Milner Round Table [article on the Internet]. No date [cited 2016 Feb 26]. Available from: https://watch.pair.com/roundtable.html

3. Dubay E. Cecil Rhode's round table groups. The Atlantean Conspiracy [article on the Internet]. c2012 [cited 2016 Feb 26]. Available from: http://www. atlanteanconspiracy.com/2008/06/rhodes-round-table-groups.html

4. Unbanned Bible Publications [article on the Internet]. No date [cited 2016 Feb 26]. Available from: http://www.unbannedbiblepublications.com/index files/ Page2982.htm

5. Illuminati Conspiracy Archive. Who controls the world? The round table group: Googling the elite's who's who [article on the Internet]. No date [cited 2016 Feb 25]. Available from: http://www.conspiracyarchive.com/ Commentary/Elite.htm

6. Bodlean Library. Correspondence of Cecil John Rhodes: 1875-1908 [collection on the Internet]. c2011 [cited 2016 Feb 26]. Available from: http:// www.bodley.ox.ac.uk/dept/scwmss/wmss/online/blcas/rhodes-cj1.html;

7. Verschoyle F. Cecil Rhodes; his political life and speeches, 1881-1900. London: Chapman Hall; 1900.

8. Clinton B. My life. London: Hutchinson; 2004, p. 78. http://dx.doi. org/10.1136/jmh.2004.000155

9. Quigley C. The evolution of society. An introduction to historical analysis $2^{\text {nd }}$ Ed. Indianapolis, IN: Liberty Fund Incorporated; 1979.

10. Sailer S. Carroll Quigley's conspiracy theory: The Milner group. The Unz Review: An alternative media selection [article on the Internet]. c2015 [cited 2016 Feb 26]. Available from: http://www.unz.com/isteve/carroll-quigleysconspiracy-theory-the-milner-group/

11. Quigley C. The Anglo-American establishment. New York: Books in Focus; 1981 